\title{
The Sociopathic Behaviour In Gone Girl
}

\author{
Krisandy Henry \\ English for Creative Industry, Faculty of Letters, Petra Christian University, Siwalankerto 121-131, \\ Surabaya 60236, East Java, INDONESIA \\ E-mail:m11413036@john.petra.ac.id
}

\begin{abstract}
Gone Girl tells the story of a woman named Amy Elliott Dunne, a woman who wants to have a perfect marriage like in a book Amazing Amy. However, real life is different from her expectation. Her husband has an affair with his student. It pushes her to do some controlling acts to manifest her wish about perfect marriage. And that is the time when Amy shows her personality as a sociopath. To know more about Amy, this study focuses on the cause and the trigger of Amy's sociopath and to identify the characteristics of Amy's sociopath through her actions and the ways she thinks. There are two results for this research. The first one is Amy shows four out of seven characteristics of antisocial personality disorder. There are failure to conform to social, deceitfulness, reckless disregard for safety, and lack of remorse. Amy is a person with sociopathic behaviour that is portrayed through her actions, such as lying, manipulating, even killing other in order to get what she wants. The second one is Amy's sociopath is caused by her parents that always give pressure to her and Amy's husband affair triggers her sociopathic behaviour. It is clear that people with antisocial personality disorder have different characteristics with normal people. The way they think and solve the problems are different from normal people.
\end{abstract}

Keywords: Antisocial personality disorder, Sociopath, Pressure

\section{INTRODUCTION}

A psychological thriller genre is a thriller story which mainly focuses on the psychology of the characters in the story and their unstable emotional states. Musack believes that "psychological thrillers often incorporate elements of mystery, drama, action, and characters may have some sort of abnormal psychological state, such as agoraphobia, anxiety, split personality of paranoia" (Musack, 2018, para 2). John Madden believes that psychological thriller focuses on story, character development, choice, and moral conflict; fear and anxiety drive the psychological tension in unpredictable ways (Bownie-Sell, 2012). In a psychological thriller, the characters often have to battle with their own inner struggle. Usually the enemies are not external (other characters or circumstances) but internal (phobias, insanity, urges, feelings, fears) (Packer, 2007). Because of this, I can assume that psychological thriller is a genre of thriller that focus on the psychology of characters within the story.

Gone Girl is one of psychological thrillers that tells about Amy Elliot, a woman who wants to have a perfect marriage like in a book Amazing Amy. Amy is described as a beautiful, famous and perfect girl. She is known as a fictional character of the most popular book with title Amazing Amy. Amazing Amy is written by her parents Rand and Marybeth Elliott. Amy's mother always controls Amy for being the same as with Amy in Amazing Amy. However, Amy's mother is actually does it for her own sake in order to get the book famously read by millions of people. Because of this book, Amy is inspired to be the real character in Amazing Amy. She also inspires and wishes to have a perfect marriage like in Amazing Amy. However, real life is different from her expectation. Her husband is not as perfect as she wants. Her husband has an affair with his student, Andie. It pushes her to do some controlling acts to manifest her wish about perfect marriage. She becomes a very manipulative person. She plans a murdered scene accurately then she leads everyone to accuse Nick as the murderer. Besides that, 
she becomes a deceitful person related to her reputation in front of the public, such as fibbing fake information about her cases of raping. And that is the time when Amy shows her personality as a sociopath. A sociopath is a term used to describe someone who has Antisocial Personality Disorder (ASPD). They often use their charm and have above-average intelligence. Hare, as cited in Huffman (2000), describes individuals with this disorder as completely lacking in conscience and empathy, they selfishly take and do what they want, violating social norms without a sense of guilt or regret.

There are two factors that cause a person become a sociopath. The first cause is genetic and the second cause is the environment. Genetics often play a role in the developing sociopathic behaviors. According to Stout, (2005) she explains that as much as 50\% percent of the cause of sociopathy can be attributed to heritability, while the remaining percentage is a confusing and not-yet-understood mixture of environmental factors. On the other hand, Huffman stated in his book entitled Psychology in Action that the cause of antisocial disorder is not completely understood, research supports both nature and nurture explanations. Evidence also exists from environmental or psychological causes (Huffman, 2000).

The cause of antisocial personality could because of a person's environment that she or he brought up or the current circumstances which he or she is going through. It can become something that trigger him or her to become a person who has antisocial personality disorder. Environmental in this case includes family, neighborhood members and friends. Good or bad treatments that he or she had received from others could also affect the personality. An individual with antisocial personality disorder often comes from homes characterized by not being taught to be respectful with the rights of others, lack of acceptance, low socioeconomic status, and antisocial from parents. Children who were treated badly by their parents may suffer serious consequences later in life. Treat badly can be physical and emotional. Physically side mostly deals with any deliberate act, behavior or physical force by an individual or individuals against someone which causes them bodily harm, injury, trauma or puts their life in danger like kicking, punching, ad burning. Next, emotionally mostly deals with controlling someone's actions and behaviors through verbal and emotional manipulation. The chance of becoming a sociopath increases when a child is subjected to this type of mistreatment. The behavior pattern that indicates antisocial personality disorder begins in childhood or adolescence and continues into adulthood (ibid).

People with antisocial personality disorder persistently violate the rights of others and often break the laws. They ignore social norms, impulsive and fail to develop interpersonal and work commitments. One of the most striking characters of the sociopaths typical is their charm. They are talking well, give the impression of being alert and clean-headed, know how to employ their skills to manipulate other people, and how to ingratiate themselves by entertaining people with exciting account of their exploits. They often show their charisma in outer appearance and have above average intelligence.

American Psychiatric Association (APA) provides a more detailed explanation about the characteristics of the people with antisocial personality disorder in book Diagnostic and Statistical Manual of Mental Disorders, 4th Edition, Text Revision (American Psychiatric Association, 2000). They formulated a set of criteria to recognize the antisocial personality (American Psychiatric Association, 2000). There are seven criteria. Failure to conform to social norms, deceitfulness, impulsivity, reckless disregard for safety, consistent irresponsibility, and lack of remorse. 


\section{AMY'S SOCIOPATH BEHAVIOR AND HER FAMILY'S ROLES}

Amy was the daughter of a famous writer named Marybeth Elliott, Amy's mother. Marybeth Elliott published a children's book titled "Amazing Amy" which tells the story of a perfect daughter, beautiful, and smart. Amy's parents always force Amy to be the same figure as in the story in writing by her mother. It is a pressure against Amy to finally affect her psychological condition when she grows up. She aspires and wishes to have a perfect marriage just like herself in Amazing Amy book. However, her real life is different from her expectation. Her husband is not as perfect as she wants which pushes her to do some controlling acts to manifest her wish about a perfect marriage. That is the time when Amy shows her personality as a sociopath in some ways. I am going to use Antisocial Personality Disorder theory in order to understand deeper the factors that influence Amy being a sociopath and what characteristics of sociopath that Amy has.

\section{The cause and trigger of Amy's sociopathic disorder}

Amy's parents play a big role in the development of her antisocial personality disorder behavior. It stars from Amy's parents that force Amy to be the same figure as in the book. Amy's childhood is constructed to be like the one in the book.

My parents are worried, of course, but how can I feel sorry for them, since they made me this way and then deserted me? They never, ever fully appreciated the fact that they were earning money from my existence, that I should have been getting royalties............ Thanks for thirty-six years of service! They deserve to think I'm dead, because that's practically the state they consigned me to: no money, no home, no friends. They deserve to suffer too. If you can't take care of me while I'm alive, you have made me dead anyway (Flynn, 2012, p. 232).

This is when Amy has been missing for five days. She is disappointed and mad to her parents because of everything that they have done to her. Amy's parents want her to be a perfect, beautiful, and smart woman, that has everything. A woman that has a perfect life and perfect marriage like a fairy tale story that has a happy ending. They never give any attention to Amy's condition. They use their own child to get money from that. It can be seen how Amy's feeling about her parents. The pressure that Amy gets for thirty-six years makes her feels sad and disappointed towards her parents. She wants to make them suffer of everything that they have done to her by killing herself. According to Morin, a psychotherapist, $(2019$, para. 6) "kids who feel like they are under constant pressure may experience constant anxiety. High amounts of stress can also place children at a greater risk of developing depression or other mental health issues." Therefore, the pressure that Amy gets to be someone else from her parents continuously affects her psychology without she realizes. In Amy's context, she has to follow all of her parents' desire. Many people may see Amy's family as the perfect family and, even though Amy's parents do not do violence, Amy's parents always demand her to be Amazing Amy. The cause of Amy sociopath is because of her parents that always give pressure to her. Nick's affair also triggers Amy's sociopathic behavior. According to Huffman "an individual with antisocial personality disorder often comes from homes characterized by not being taught to be respectful with the rights of others, lack of acceptance, low socioeconomic status, and antisocial from parents" (2000, p. 59). In Amy's context, Amy's parents have always seen Amy as Amazing Amy, not Amy. Amy's attitude, interest, hobby, life have to be the same as Amazing Amy. Her parents always force Amy to be Amazing Amy. Amy's parents never give Amy a choice to be herself. They also never give what Amy wants. Therefore, it affects Amy's attitude. She cannot accept failure in her marriage. She thinks they can be the happiest couple, but she is wrong. She feels disappointed to Nick. She becomes a person who is very different from what Nick usually sees. She becomes deceitful and manipulatives. The pressure that Amy gets from her parents 
start since her childhood until her marriage. She has to obey all her parents demand. First, she has to be smart, beautiful, and perfect is the first demand that she has to do to become Amazing Amy. She has to learn many lessons and do many activities or hobbies. Second, she has to marriage and has a perfect marriage like in the book. However, her marriage does not go as what she expects. Her perfect marriage is destroyed because of Nick's affair.

I got there just in time to see him leaving with her. I was in the goddamn parking lot, twenty feet behind him, and he didn't even register me... He didn't have his hands on her, not yet, but I knew. I could tell because he was so aware of her. I followed them, and suddenly, he pressed her up against a tree - in the middle of town and kissed her. Nick is cheating, I thought dumbly, and before I could make myself say anything, they were going up to her apartment.... He never even knew I knew (Flynn, 2012, p. 228).

This is the quotation when Amy goes to Nick's bar because she wants to give Nick's surprise. In her surprise, she finds Nick with a young girl who looks like his student named Andie. She finds that Nick has an affair with her. Amy is trying to act as if everything is fine but Nick's affair with Andie makes Amy cannot forgive that. He breaks everything that Amy has built. He breaks the perfect marriage of Amazing Amy and it triggers her sociopath side.

I could hear the tale, how everyone would love telling it: how Amazing

Amy, the girl who never did wrong, let herself be dragged, penniless, to the middle of the country, where her husband threw her over for a younger woman. How predictable, how perfectly average, how amusing. And her husband? He ended up happier than ever. No. I couldn't allow that. No. (Flynn, 2012, p. 228).

Nick must be taught a lesson. He's never been taught a lesson! (Flynn, 2012, p. 229).

This is the quotation of what Amy thinks if everyone knows that her husband has an affair. She does not want to fail to be an Amazing Amy because of Nick's fault and she also does not want everything that she has built become useless. She wants Nick to suffer because of everything that he has done to her. She thinks Nick deserves to be punished and it is not her fault if she has to do bad things to him. Therefore, she plans a revenge by using her intelligence in manipulating a situation. In Amy's context, she will do anything to be Amazing Amy. Because Nick breaks her plan to have a perfect marriage, Amy shows her true identity. She becomes a deceitful person. She plans to do the manipulation to hurt Nick. She cannot accept her failure. She must have a perfect marriage, because she cares of what others think about her. The pressure that she gets for being Amazing Amy is also give a big impact for her, because she tries to be someone. Therefore, all these pressures give big impact to Amy's psychology to become a sociopath.

In conclusion, the cause of Amy sociopath is because of her parents that always give pressure to her. The pressure that Amy gets from her parents start since her childhood until her marriage. She has to obey all her parents demand. First, she has to be smart, beautiful, and perfect is the first demand that she has to do to become Amazing Amy. She has to learn many lessons and do many activities or hobbies. Second, she has to marriage and has a perfect marriage like in the book. However, her marriage does not go as what she expects. Her perfect marriage is destroyed because of Nick's affair. She cannot accept her failure. She must have a perfect marriage, because she cares of what others think about her. The pressure that she gets for being Amazing Amy is also give a big impact for her, because she tries to be someone. Therefore, all these pressures give big impact to Amy's psychology to become a sociopath.

\section{Amy's Sociopath Behavior through Manipulations}

Amy, a sociopath, uses her intelligence to plan manipulations and to cover her real agenda. However, it is not easy to do manipulation. It needs high intelligence and very detail person to 
do the manipulation. This manipulative behavior apparently is seen in Amy's actions. Amy often manipulates others to fulfill her desire and she makes use of her charm in order to make others like her until she can manipulate them. She lives in the delusion of "perfect marriage" and has an unhealthy attachment to Nick. Therefore, when the marriage does not work like she hopes (Nick cheated on her), she manipulates the situations in order to hurt Nick and then to get back together again with him.

Amy manipulates the situation to get revenge by hurting Nick. She uses other people as a tool. She needs a pliant friend for her fake pregnancy plan, someone she can load up with awful stories about Nick, someone who will become overly attached to her, and someone who is easy to manipulate.

It started with my vacant brained friend Noelle. The Midwest is full of these types of people: the nice enoughs. Nice enough but with a soul made of plastic - easy to mold, easy to wipe down. The woman's entire music collection is formed from Pottery Barn compilations. Her bookshelves are stocked with coffee-table crap: The Irish in America. Mizzou Football: A History in Pictures (Flynn, 2014, p. 252).

This quotation above shows that Amy chooses Noelle, Amy's neighbor, as a friend is because Noelle Hawthorne is not particularly smart, which is precisely why Amy chooses her. Amy considers Noelle not as a friend, but as a fool "My vacant brained friend Noelle" shows the way Amy thinks about Noelle. Because Noelle is easy to be fooled, this is the reason why Amy wants to be friend with Noelle. She wants to take the advantages from Noelle.

Noelle was the obvious choice, and when she told me she was pregnant again - triplets weren't enough, apparently - I realized I could be pregnant too. (Flynn, 2012, p. 252).

This quotation above is one of the reasons why Amy choose Noelle as one of her plans. Because Noelle is pregnant, then this is Amy's chance to get pregnant. I see the way Amy's think is different from normal people. Usually when someone get pregnant, someone of his or her friend also feels happy because of the pregnancy. Different with Amy, she thinks this is an opportunity to get pregnant. She tries to take advantages from Noelle.

From all of Amy manipulative actions and the way she thinks, I see that Amy possesses four characteristics of antisocial personality disorder according to American Psychiatric Association. First is failure to conform to social. In Amy's context, she uses her intelligence to do bad things, such as faking her own death, killing her ex-boyfriend and many other things. From those actions that she has done, she breaks all the norms and she cannot follow the social norms rules. Second is deceitfulness. In Amy's actions that she has done, it can be seen that she lies about her pregnancy, her diary, her murder and many other things. She does all those things to get what she wants. Third is reckless disregard. One of the examples that shows she does not care about herself or other people when she hurts herself in order to make a perfect murder. She also kills ex-boyfriend in order to make cover her true agenda. Fourth is lack of remorse. She does not feel anything is wrong of what she does, and she proud of everything what she does, because she thinks she is right. Through this analysis I can conclude that Amy is a sociopath because Amy possesses four of characteristics of antisocial personality disorder.

\section{CONCLUSION}

This study has discussed the causes and characteristics of Amy's sociopath in Gone Girl. In order to reveal that, I use antisocial personality disorder theory by Huffman and American Psychiatric Association. By applying Huffman's theory, I find that the cause of sociopath is because of her parents. I also find that Amy possesses four characteristics of sociopathic behavior. 
By understanding this, I learn people can become a sociopath because of the pressure of environment which, in this case, is parents. The pressure of the parents sets a foundation for children to develop a sociopathic behavior. The pressure can be resulted from the parents' bad parenting. One of the examples of bad parenting is how the parents try to control the children's actions or behaviors without letting the children to have choices. The pressure that the children get from the parents can affect their character development, ways of thinking, and choice of actions. Therefore, some who get pressure by their parents can cause them to have sociopathic behavior In addition, sociopaths have different way of thinking from normal people. For example, the reason why sociopaths lie to someone is different from what normal people think. Normally, when normal a person lies to someone, he or she will feel guilty, however,

Sociopaths do not feel that lying is something is wrong. They blame other people fault if they do bad thing. In Amy's case, she does not feel that hurting Nick is something wrong, because she thinks Nick deserve to be punish of everything he has done to her.

In conclusion, sociopaths are people who have antisocial behaviour especially be marked with the less empathy for other people, combined with abnormal behavior and difficulty to socialize with other people. The reason why someone becomes a sociopath is either because of genetic or environment. Environment in this case is parents. The closest environment that can affect the children's character development is their parents because their parents are the ones who guide them while they are growing up. As a result, it is possible for the children to develop deviant behavior if their parents perform poor parenting. It is clear that people with antisocial personality disorder have different characteristics from normal people. The way they think and solve the problems are different from normal people.

\section{REFERENCES}

American Psychiatric Association. (2000). Diagnostic and Statistical Manual of Mental Disorders, 4th ed. Washington, DC: American Psychiatric Association

Bownie-Sell, D. (2012). John Madden on psychological thrillers. Retrieved October 23, 2018, from https://www.telegraph.co.uk/culture/film/starsandstories/9032326/John-Maddenon-psychological-thrillers.html

Flynn, Gillian. (2012). Gone Girl. New York: Crown Publishing Group.

Huffman, Karen, Mark V and Judith V. (2000). Psychology in Action, $5^{\text {th }}$ ed. New York: John Wiley \&Suns Inc

Musack. (2018). Psychological Thrillers and Psychological Suspense. Retrieved March 12, 2019, from https://www.bcls.lib.nj.us/psychological-thrillers-and-suspense

Packer, S. (2007). Movies and the Modern Psyche. America: Greenwood Publishing Group

Stout, M. (2005). The Sociopath Next Door. New York: Harmony 